\title{
$\mathbf{A l}-\mathbf{Z n}_{\mathbf{n}}$ 系合金の過冷 $\beta$ 固溶体における析出現象についで
}

\section{森永 卓一** 高橋 恒夫***}

\begin{abstract}
On the phenomena of precipitation in super cooled $\beta$ phase
\end{abstract}
of aluminium-zinc system*

$(\mathrm{UDC} 621 \cdot 785 \cdot 6 \cdot 7: 669 \cdot 715 \cdot 5)$

MORINAGA Takuichi** TAKAHASHI Thuneo***

\begin{abstract}
When the supersaturated solid solution " $\beta$ " of Al- $\mathrm{Zn}$ alloy is quenched from the rang above eutectoid line, the precipitation goes on at room temperature. The percipitation rate gets slow down, however, when small amount of magnesium or cadmium is added to the alloy.

Experiments have been made to study on the precipitation process by means of measuring temperature, specific heat, electric resistance and thermal expansion. For the experiments, zinc alloys with $5 \sim 65 \%$ aluminium (every $5 \%$ ) and znic alloy with $21 \%$ aluminium and $0.01 \sim 0.03 \%$ magnesium have been used as specimens.

From the above-mentioned experiments, it was found out that the rapid precipitation which is seen in the supersaturated solid solution " $\beta$ " of $\mathrm{Al}-\mathrm{Zn}$ alloy is probably due to the existance of vacant latices and magnesium, when added, decreases or extinguishes the vacant latices.

It was also found out that small amount of magnesium probably promotes the formation of G-P Zone at room temperature.
\end{abstract}

(Received Apr.25, 1960)

\section{1. はしがき}

$\mathrm{Al}-\mathrm{Zn}$ 系 $\beta$ 固溶体は共析変態点以上の温度から急冷乙 ても常温で析出が進行してしまうがこれに $\mathrm{Mg}, \mathrm{Cd} な$ ぞを少量添加することにより析出速度を遅延させること ができる1 5)。

この $\beta$ 固溶体に抢ける析出過程について大日方博士 ${ }^{31}$ は結晶学的立場より準安定の中間相の存在を認めず，よ く物理的諸性質の変化を説明している。また加藤氏5は $\mathrm{Zn}-\mathrm{Al}-\mathrm{Mg}$ 三元状態図から推測して微量の Mg の添加 が焼杘しに際して強さおよび硬さを高める原因として金 属間化合物 $\theta\left(\mathrm{Mg}_{2} \mathrm{Zn}_{11}\right)$ を硬化要素とする析出硬化 を考党た。一方この合金系の析出を理論的に取扱らため $\boldsymbol{K}$, Borelius ${ }^{6)}$ 7) は共析温度以上での $\boldsymbol{\beta}$ 固溶体の溶解度 曲線より “Spinodal curve”を求めており, Garwood および Hopkings ${ }^{8)}$ は T-T-T 曲線を求め動力学的な 考察を行なつている。

以上の上5飞 Al- Zn 系合金の過冷 $\beta$ 固溶体の析出に
ついて多くの研究は岁るが，著者らは 5 〜 $65 \% \mathrm{Al}$ を含む $\mathrm{Al}-\mathrm{Zn}$ 合金および21\%Alをふくむ合金飞微量 $\mathrm{Mg}$ を添 加した合金について，発熱温度および比熱測定，電気抵 抗ならびそ熱膨張などの測定を行ない，室温および昇温 析出現象を研究し, その析出機構についての一考察をし た。

\section{2. 試料の作成および実験方法}

\section{1 試料の作成}

実験飞用いた地金は再電解再鉛 (99.99\%以上) と再電 解アルミニウム (99. 99\%以上)を用い，マグネンウムは 99.9\%以上の地金を使用した。合金は上質黑鉛ルツボ中 で融解した。そして電気抵抗測定用試料としては $5 \mathrm{~mm} \phi$ 金型飞，また熱的測定用としては $15 \mathrm{~mm} \phi$ 金型飞鋳込ん だ。

融解，鋳造した試料の配合成分は $\mathrm{Al}-\mathrm{Zn}$ 系二元合金 では $\mathrm{Al} 5 \%$ から $65 \%$ まで $5 \%$ おきの13種類と $\mathrm{Al} 21 \%$ に $\mathrm{Mg}$ を0.01および $0.03 \%$ 添加した合計 15 種類である。

* 昭和 25 年 9 月 日本金属学会で一部発表

** 東京工業大学 工博 Prof,, Tokyo Institute of Technology, Dr. Eng.

*** 東京工業大学 Tokyo Institute of Technology. 


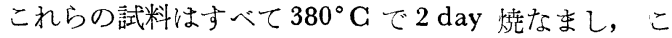
れを $250^{\circ} \mathrm{C}$ の共析点以下の温度まで徐冷して, 再び 4 day 焼なるしを行なつて均一化したものを平衡状態 試料とした。

\section{2 実験方法}

実験としては発熱反応温度測定，比熱測定，電気抵抗 ならびそ熱膨張測定を行なつた。

析出初期飞共析組成近傍の合金では発熱反応がみれる がこの温度を正確に測定するためにポテンンョメーター で起電力を読えで温度測定を行なつた。この温度測定に 用いた試料は直径 $15 \mathrm{~mm} \phi$, 高さ $20 \mathrm{~mm}$ の円壔状であり この一部に直径 $2 \mathrm{~m} \mathrm{~m}$ の孔をあけ約 $0.1 \mathrm{~m} \mathrm{~m} \phi$ の銅一コ ンスタンタン熱電対を挿入して測定した。このよ5に温 度測定を行ならと析出時間と発熱温度をかなり正確に測 定できる。

比熱測定は長崎一高木式の熱量款 の)を用い，試料は析 出初期の発熱反応温度を測定したものと同一のものであ つて, 加熱速度は熱異常変化のない際は $2^{\circ} \mathrm{C} / \mathrm{min}$ 。で ある。熱澎張測定も比熱測定に用いた試料と同一のもの で加熱速度も異常変化のない際は $2^{\circ} \mathrm{C} / \mathrm{min}$.で行なつ た。電気抵抗測定は直径 $5 \mathrm{~mm}$, 長さ $120 \mathrm{~mm}$ の試料で 約 $1 \mathrm{Amp}$ の電流を流し電位差法によつた。

\section{3. 実験結果およびその考察}

\section{1 常温析出現象}

Fig. 1 は $\mathrm{Al}$ 含有量を変えた場合の $\mathrm{Zn}-\mathrm{Al}$ 合金を365 ${ }^{\circ} \mathrm{C}$ ょり $0^{\circ} \mathrm{C}$ の水中急冷して直ちにポテンンヨメータ 一飞よる熱起電力測定により発熱温度を求めた曲線であ

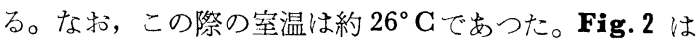
$365^{\circ} \mathrm{C}$ 上り急冷した試料の常温析出中に打汗る電気比抵 抗值であつて，実際の電気比抵抗值を図示すると重なつ てしまうので目盛をずらして示してあるが，その変化量 拈よび析出時間は明らかてわかる。Fig.3 沈これをさら 飞長時間の常温析出中の抵抗值測定結果である。

Fig. 1 の熱的変化をみると，共析点以下の巠共析合金 そおいてはその発熱の最高温度に達する時間, すなわち

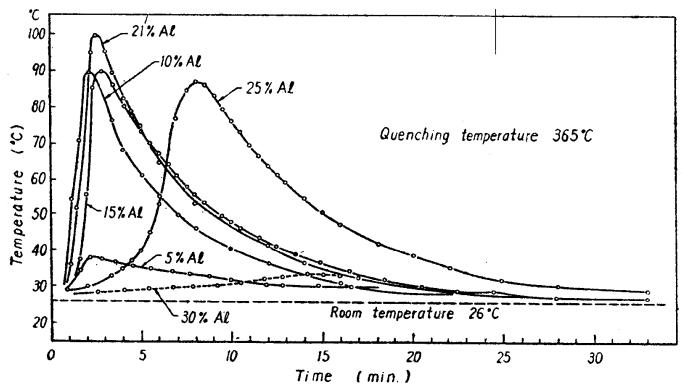

Fig. 1 Change of temperature during precipitation at room temperature (at $26^{\circ} \mathrm{C}$ ).
析出速度の最大と考兄られる時間飞達するまでは約 2 3 min. であつて Al 量が10〜21\%とかわつて毛卧隹同一 時間であり，Al含有量が多くなつて共析合金に近づくは ぞ発熱による温度上甼が大きくなり，21\%Alの共析合金 ではこの温度上昇は $100^{\circ} \mathrm{C}$ 亿も達している(室温 $26^{\circ} \mathrm{C}$ )。 さらに Al 含有量の多い超共析合金である $25 \% \mathrm{Al}$ 合金で は最高温度に達する所要時間は $8 \sim 9 \mathrm{~min}$. と遅れ，そ の温度も21\%Al 合金よりも低くなつてくる。これが 30 \%Al合金となるとわずかな発熱しか認められず最高温度 飞達するのに15 min.を要している。40\%Al 以上では析 出がさらに遅くなり，発熱現象は認められない。電気抵 抗測定から析出現象を検討すると，Fig. 2 からもわかる

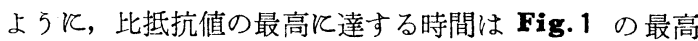
温度に達する時間とほぼ一致している。以上のような熱

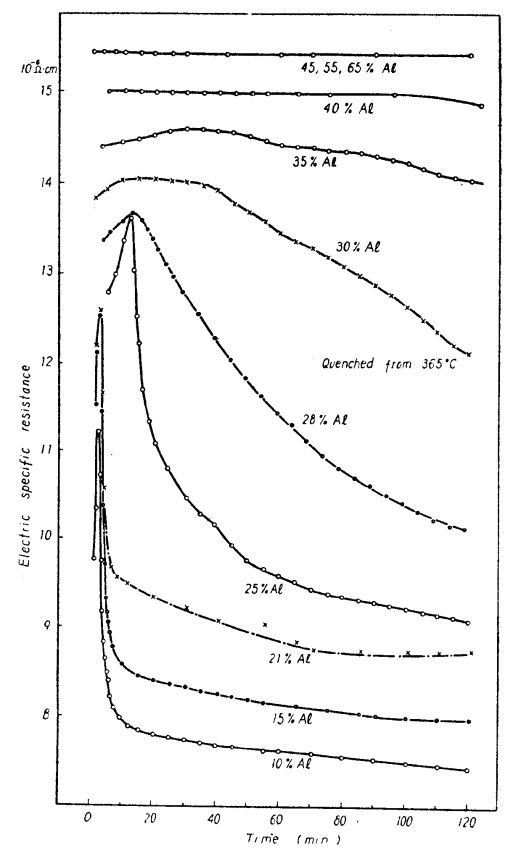

Fig. 2 Change of electrical resistance during precipitation at room temperature.

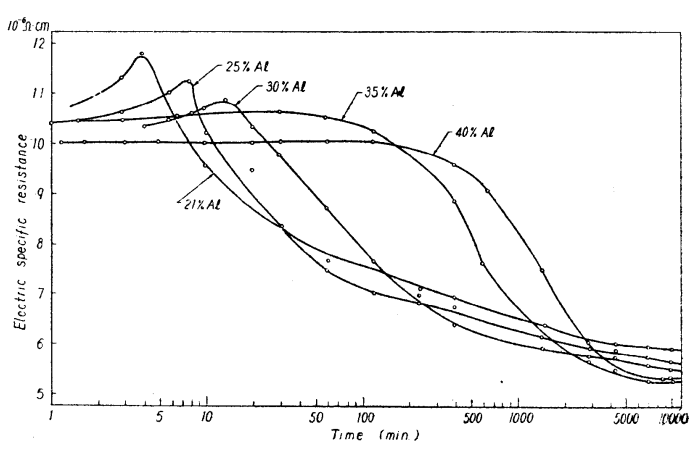

Fig. 3 Change of electrical resistance during room temperature aging. 
的および電気抵抗測定から双ると，共析組成までの亜共 析合金では，注涪同一時間たつたところで析出速度の最 大があらわれ，超共析合金では Al 濃度が大きくなると したがつて変化が遅れていることなどから，これは $\beta$ 相 の分解基因吉ることは明らかである。なおFig.3 の電 気抵抗測定結果は約 7 day までであるが，実験は 25 day まで行なつた。この結果によると測定精度以内で注淁抵 抗値は一定となり，これを昇温焼もごしてみると焼もど 乙試料と同一の曲線で, 特に異常は認められず, 安定状 態飞復㷌している。

つぎ $21 \% \mathrm{Al}$ の共析合金飞お汗る焼人れ温度と析出 速度との関係について実験を行なつた。この実験注共析 温度以上の種々の温度に保持して後々の温度より $0^{\circ} \mathrm{C}$ の 一定温度の水中に急冷して発熱現象をしらべた。焼入れ 温度を変えて为発熱現象は Fig. 1 の $21 \% \mathrm{Al}$ 合金を $365^{\circ} \mathrm{C}$ から急冷した場合と同一傾向であつて,この結果をFig.4 (a) 飞図示した。この曲線からわかる上う飞焼入れ温度 を上げて行くと最高温度に達する時間は長くなる。すな わち析出速度は焼入れ温度を上げると遅滞するという現 象が認められた。また析出速度が小さくなつているとい うことをさらに明らか反するために上記の発熱現象測定 を行なつて燒入れ後 $2 \mathrm{hr}$ 経過してから，これを加熱し

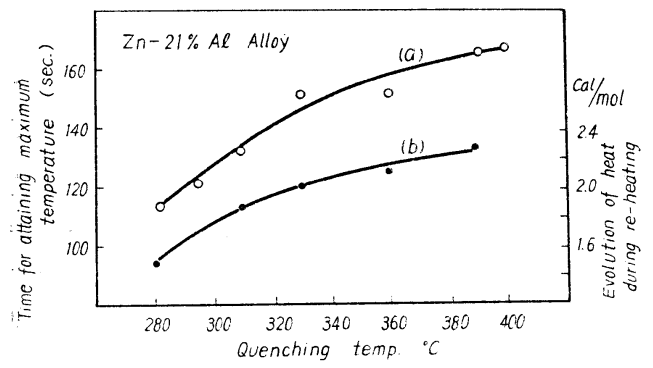

Fig. 4 Effect of quenching temperature on the rate of precitation and the retained thermal energy value.

a. Rate of precipitation in therms of required time to get maxmum temperature after quenching.

b. Retained thermal energy after two hours natural aging.

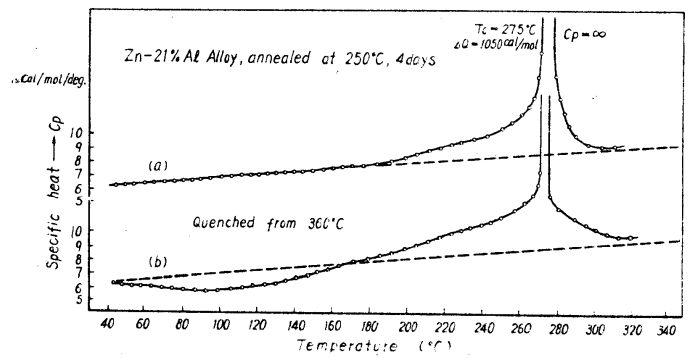

Fig. 5 Specific heat change during slow heating.
未分解 $\beta$ を安定化する間にどのくらいの熱エネルギーを 放出するかを測定した。Fig.5 (b) は $360^{\circ} \mathrm{C}$ から焼入れ した $21 \% \mathrm{Al}-\mathrm{Zn}$ を $2 \mathrm{hr}$ 常温汸放置した後昇温加熱した 際の比熱曲線であり，他の焼入れ温度の場合でるほぼ同 様の曲線となる。Fig.5（a) 法なま乙試料の比熱曲線 であつて焼入れ試料はすべて $180^{\circ} \mathrm{G}$ 以上で安定状態にも ぞつていることがわかる。Fig.4 (b) 飞比熱測定から求 めた発熱エネルギーと，焼入れ温度との関係を示した。

Fig.4 (a) および (b) 上り焼入れ温度も高いすると析出 初期の析出速度が遅滞することがわかる。な掞この常温 析出飞打汁る発熱現象は $21 \% \mathrm{Al}-\mathrm{Zn}$ 合金汇 0.01 打よび $0.03 \% \mathrm{Mg}$ を添加した試料ではみとるられないことは以 前の報告と同一である。ここで微量の $\mathrm{Mg}$ あるいは $\mathrm{Gd}$ が常温析出を遅滞させる原因を考えよ5。Ellwood10) は $\mathrm{Al}-\mathrm{Zn}$ 系合金で $\mathrm{Al}$ 65\%以上の $\mathrm{Al}-\mathrm{Zn}$ 合金につい て空位格子 (vacancy) の数を実験的飞求め, 25 at\%で 約 $2 \%$ 空位格子が存在することを報告している。従つ て前述の焼入れ温度により析出速度が変ることなどから Al 含有量の少ない共析点近傍の合金でも空位格子が存 在し，これが常温析出を促進寸るものと思われる。そし てこの合金微量 $\mathrm{Mg}$ あるいは Cd を添加寸ると空位 格子が減少またはなくなり析出が抑制されるのではない かと考える。さらに Mg を添加したような場合飞加藤 氏の考壳ているような三元化合物が生成されるのではな かららか。

\section{2 昇温焼戻し析出現象}

\subsubsection{Mg を添加しない場合}

Fig. 6 は Fig. 2 亿示したと同様烧入れ後 $2 \mathrm{hr}$ 常温 析出を行なわさせた後ただちに昇温焼戻しを行なつた 埸合の電気抵抗值の変化を示す。この図测定值をその まま図示するとわかりにくくなつてしまうので目盛をず らして示してある。またすべての試料について常温まで の冷却曲線をも求めたがここには示してない。この曲線 より常温析出させた後の未分解 $\beta$ 上り安定状態への移行 の状況がわかる。初期析出を常温で行なつた後の昇温加 熱飞際しての熱変化は Fig. 5 に示したように，常温析 出速度が大きいような試料では未析出部分が少なくなり 熱変化を測定できるが， $\mathrm{Al}$ 含有量が多くて常温析出の 遅れている試料では発熱量が大きくなり測定が困難にな つてくる。

$35 \% \mathrm{Al}$ では $80^{\circ} \mathrm{C}$ 以上になると急激な発熱を示し，そ れ以後は十分な測定ができないが， $45 \% \mathrm{Al}$ では $140^{\circ} \mathrm{C}$ 付近に発熱の㥛少が認められ，析出は急激でないことが わかる。

上述のような昇温の際の電気抵抗ならびそ熱測定から 昇温の際の析出の速度の大きい温度を求めるために, 電 気比抵抗值の温度係数の極少值および発熱の最大值を示 
す温度を求めた。この温度を $\mathrm{Al}-\mathrm{Zn}$ 状態困とともに

Fig. 7 (a) に示しまた昇温焼戾しにより平衡状態に達す る温度を Fig.7(b) 飞示す。これからわかるように共析 点の合金が平衡状態に達する際には最大析出速度になる ような温度が最低とはなつていないことがわかる。この 結果はFig. 8 亿示す Spinodal curve7) や G-P Zone などの範囲を考える場合の一資料になると考える。

\section{2 .2 共析合金飞微量 Mg を添加した場合}

$21 \% \mathrm{Al}$ 合金に0.01\% および $0.03 \% \mathrm{Mg}$ を添加した試料 を $365^{\circ} \mathrm{C}$ より焼入れし昇温焼戾し中の比熱，電気抵抗括 よび熱膨張変化を測定した。

$21 \% \mathrm{Al}$ 合金に0.03\% Mg を加えた合金の電気抵抗変 化を Fig.9 そ，熱膨張変化を Fig.10 そ，また比熱

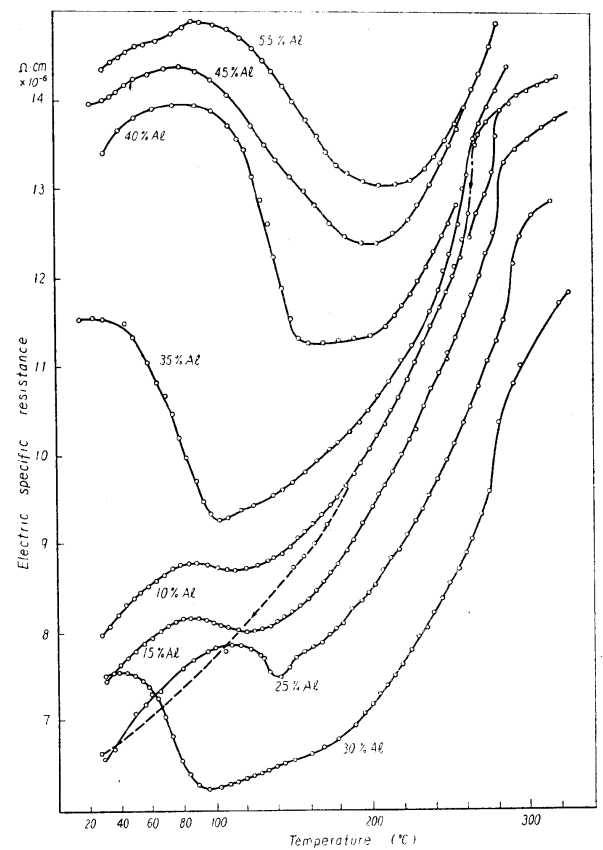

Fig. 6 The electical resistance change during aging caused by heating.

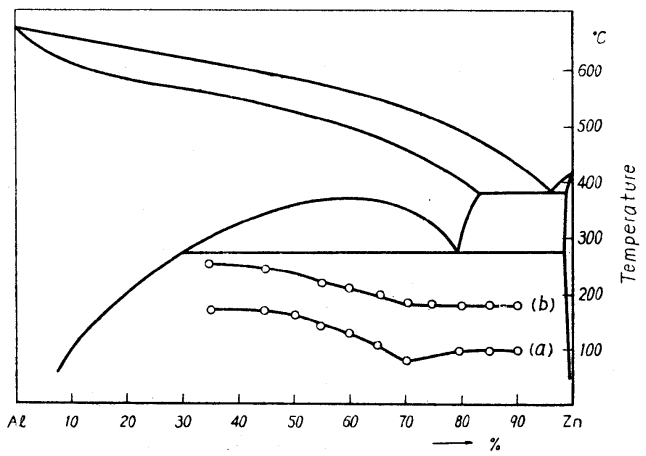

Fig. 1 The equilibrium diagram of $\mathrm{Al}-\mathrm{Z}_{\mathrm{n}}$ system.
の変化を Fig.11（c）に示す。0.01\% Mg 合金もこれ らとほぼ同様の曲線を示す。これら電気抵抗, 熱膨張, 比熱の測定より，微量 $\mathbf{M g}$ を添加した際に焼入れ昇温。 焼戻しを行なうと，ほぼ $100^{\circ} \mathrm{C}$ 近くまでに第 1 段の変化 があり，次いで $140^{\circ} \mathrm{C}$ ぐらいまで第 2 段， $180^{\circ} \mathrm{C}$ まで第 3 段の変化が認められた。この第 1 段の変化は熱膨張に おいてはわずかな膨張をおこし，熱変化では吸熱変化が 認められる。続いて第 2 段の変化に当る $135^{\circ} \sim 140^{\circ} \mathrm{C}:$ 近くまででは熱膨張，電気抵抗ともに急激な変化はない が，熱的にはこの間では発熱現象となる。さらに温度を 上げると急激な発熱を生じ, 熱膨張, 電気抵抗はともに 減少して $180^{\circ} \mathrm{G}$ で最小値となる。それ以上の温度では完: 全に安定状態となり析出は完了してしま5。この第 1 段.

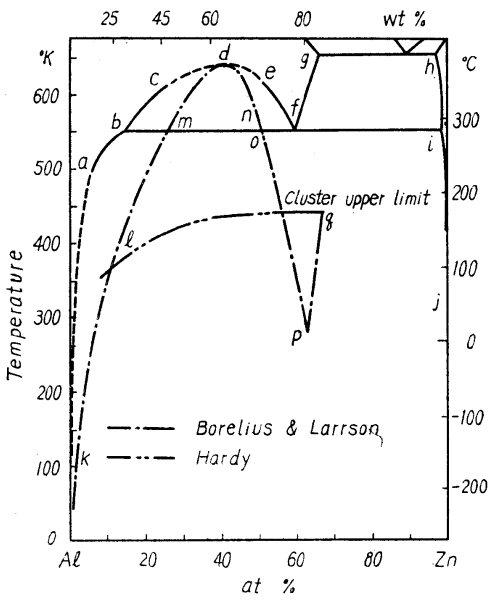

Fig. 8 Two phase boundaries calculated spinodal curve and supposed upper limit of the Guinier-Preston aggregates in the system Al-Zn. (by G. Borelius)

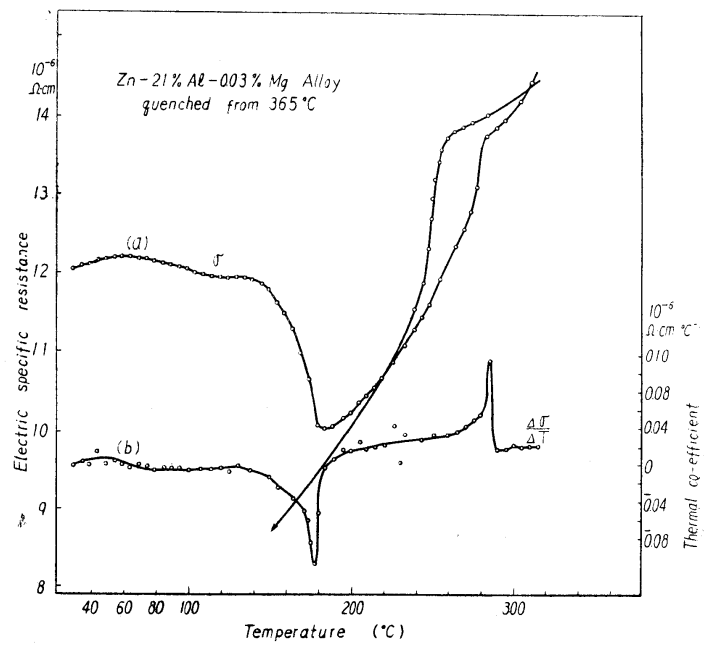

Fig. 9 Electrical resistanc and its thermal coefficient changes during aging caused. by heating. 
および第 2 段にわたる変化をさらに究明するため $365^{\circ} \mathrm{C}$ 加ら焼入れ後 1 度 $100^{\circ} \mathrm{C}, 30 \mathrm{~min}$. の焼戻しを行ない, 次 いで再び加熱して比熱曲線を求めたのが Fig.11(d) で ある。これを Fig.11（c）の焼入れしたままの試料の場 合と比較すると第 1 段の $100^{\circ} \mathrm{G}$ 近くまであつた吸熱はほ とんど忍められず 90 〜 $95^{\circ} \mathrm{C}$ からずかな発熱がおこる。 しかしこの発熱は非常に徐々であつて $135^{\circ} \mathrm{C}$ 近くより再 び急激な変化となる。この際の第 2 段に打ける発熱量は

Fig.11（c)，Fig.11（d）を比較してもわかるように焼 入れしたままのものよりもすくなくなつている。

以上のよ 5 亿加熱過程中に吸熱現象がみられるのは, $\mathrm{Al}-\mathrm{Cu}$ 合金の常温時効または低温時効 $\left(130^{\circ} \mathrm{C}\right.$ 以下) $飞$ おいて G-P Zone が生成されていてこれを焼戻した際 認められる現象と同様であり, 従つて $100^{\circ} \mathrm{C}, 30 \mathrm{~min}$. の焼戻しにより，常温で生成されていた G-P Zone が Matrix 中に再分散されてしまうので，これを再び加熱 しても吸熱現象はあらわれなくなつたものと考える。す なわち微量 $\mathrm{Mg}$ の添加により常温析出を抑制するかわ り G-P Zone 飞を生成することが考えられる。また第 2 段変化の $100 \sim 140^{\circ} \mathrm{C}$ 飞打ける変化は加藤氏の強調し ている $\theta$ 相の析出と考劣れば一応説明がつく, しかし一 方この測定に拈ける加熱速度が $2^{\circ} / \mathrm{min}$. ぐらいなので $\mathrm{Al}-\mathrm{Cu}$ における $\theta^{\prime}$ 相のような中間相をへて次の析出ま で進行しているとも考えられる。いずれにして G-P Zoneを生成していると考えられる物質が何んであるか, また第 2 段の変化は化合物の析出か中間相の析出である かは，第三元素としての Mg の他に Cd などを添加し

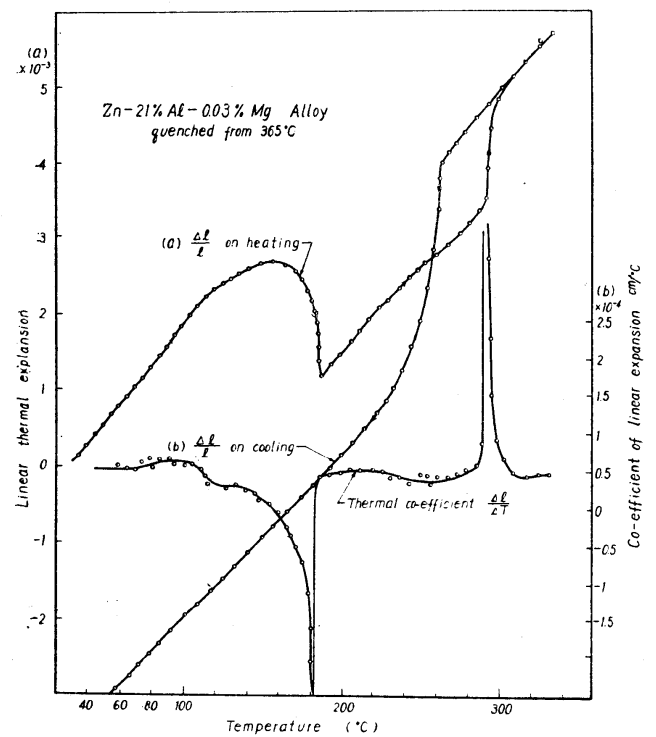

Fig.10 Dilatation and change of co-efficient of linear expansion during aging caused by heating.
てみたり,さらにX線的の証明をしたりすることが必要 であり，今後さらに検討すべき点であると思う。

\section{4. むすび}

$5 \sim 65 \% \mathrm{Al}-\mathrm{Zn}$ 二元系合金および21\%Al-Zn VMgを 微量添加した合金について常温析出および昇温焼戻し析 出現象を調べた。その結果次のようなことが明らかとな つた。

1. Al-Zn 合金を共析温度より急冷すると常温で析 出が進行するが $\mathrm{Al}$ の濃度により析出速度に非常に差異 がある。

2. 焼入れ温度を高めると常温飞执ける析出はわずか 遅滞する。これは, 空位格子の生成と関係があると考え る。

3. 昇温焼戾し析出の際の最大析出速度を有する温度 および安定状態に達する温度は共析点のとさが最低とは ならない。

4. 共析合金飞微量 $\mathrm{Mg}$ 学添加すると常温析出を抑 制され，G-P Zone が生成されるようになる。

終りに臨久, 本実験の遂行に種々御便宣を計つて下さ つた高木豊先生に深く感謝致します。

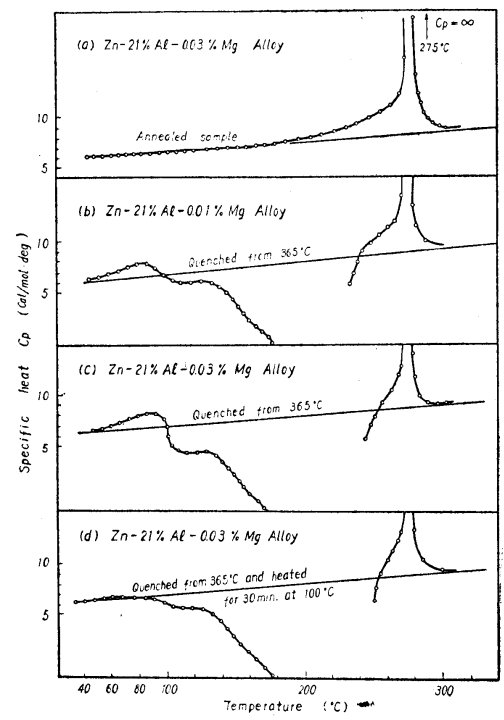

Fig. 11 Change of specific heat during heating.

参考文 献

1) D. Hanson and M. Geyler : J. Inst. Metals 27 (1922) 267.

2）今井, 萩谷 : 鉄と鋼 20(1934)718;22(1936)37.

3) 大日方, 萩谷, 市村 : 鉄と鋼 22(1936)622.

4) 森永：日本金属学会誌 5 (1941) 49 .

5) 加藤 : 今井教授記念論文集 (1958) 115.

6) G. Borelius : J.Inst. Metals(T.A.I.M.M.E) 
3 (1951) 477.

7) G. Borelius and L. E. Larrson; Arkiv. Metal Astron. Fysik. (1) $35 \mathrm{~A}$ (1948) 13.

8) R. D. Garwood and A. D. Hopkins : J. Inst.
Metals 1952 53 Vol. 81, 107.

9）長崎, 高木: 応用物理 17 (1948).

10) E. C Ellwood; J. Inst. Metals 1951 52 Vol. 80217.

\section{海 外 交 献 紹 介（2)}

\section{ALLUMINUM AND ITS ALLOYS}

3) 分 析

* Use of 8-hydroxyquinoline for the fluorimeter determination of aluminum in steel. Rensselaer Polytechnic Institute. 1950. 33p.

* Analysis of degassing 90 aluminum-10 magnesium alloys. U. S. Naval Ardnance Test Station. 1949. 32p.

* Spectrographic analysis of aluminum powder, atomized, type C.class D. U.S. Naval Powder Factory. 1953. 15p.

* Measurement of gas in aluminum melts. U.S. Frankford Arsenal. 1949. 34p.

* Development of composite spectrophotometric procedure for the analysis of low-alloy steels and of aluminum and its alloys. University of Texas. 1952. 68p.

* Recommended methods of the Panel on Method of Analysis. (Aluminum determination, etc.) U. S. Ordnance Dept. Metallurgical Advisory Committee on Titanium. 1955. 73p.

* Composite spectrophotometric procedure for the analysis of low-alloy steels and of aluminum alloys. U. S. Air Force. Wright Air Development Center. Material Lab. 1955.41p.

* Polarographic determination of gallium in aluminum alloys. U.S. Air Force. Wright Air Development Genter. Material Lab. 1956.19p.

* Spectrographic determination of lithium in aluminum metal. Gt. Brit. Atomic Energy Research Establishment. 1955. 7p. (AERE C/ R196)

* X-ray spectroscopy of solids. (Aluminum, argon, copper, zirconium, etc.) Ohio State University Research Foundation. 1956. 75p.
* Gravimetric determination of aluminum in titanium alloys. U. S. Arsenal, watertown. 1955. 14p.

* Photometric determination of small amounts. of aluminum in steel using 8-hydroxyquinoline. U.S. Arsenal, watertown. 1955. 18p.

4) 異 方性

* Experimental and theoretical investigation of the anisotropy of $3 \mathrm{~S}$ aluminum alloy sheet in. the plastic range. U. S. NACA. 1954. 45p. (NACA TN 3248)

5) 棒

* Fatigue crack propagation in severely notched bars. (2024-T4 alnminnm alloy extruded ronnd rods). U. S. NACA. 1956. $31 \mathrm{p}$.

* Static strength of cross-grain 7075-T6 aluminum-alloy extruded bar containing fatigue cracks. 1957. 25p. (NACA TN 3994)

6) ビーム, アングル

* Calculation and measurement normal modes of vibration of an aluminum-alloy box beam with and without large discontinuities. U. S. NACA. 1953. 40p. (NACA TN 2884)

* Effect of prestraining on the strength of aluminum alloy struts. Gt. Brit. Royal Aircraft Establishment. 1949. 13p.

* Investigation of short colum formulae as applied to aluminum angles. Rensselaer Polytechnic Institute. 1949. 46p.

* Experimental investigation of the pure-bending strength of 75S-T6 aluminum-alloy multiweb with formed-channel webs. U.S. NACA. 1954. 30p. (NACA TN 3082)

* Fatigue-crack propagation in aluminum-alloy boxbeams. U. S. NACA. 1956. 33p. (NACA TN 3856) 